\author{
PaWek Jankowski ${ }^{*}$ \\ Uniwersytet Mikołaja Kopernika w Toruniu
}

\title{
OCHRONA ŚRODOWISKA W WYCENIE PRZEDSIĘBIORSTWA NA PRZYKKADZIE WYKORZYSTANIA OPCJI RZECZYWISTYCH
}

Słowa kluczowe: ETS, EU ETS, ochrona środowiska, opcje rzeczywiste, wartość przedsiębiorstwa.

Klasyfikacja JEL: G23, Q51, Q52.

\begin{abstract}
Abstrakt: Celem artykułu jest przedstawienie możliwości wykorzystania narzędzi ochrony środowiska do zarządzania i wyceny przedsiębiorstwa. W artykule zaprezentowano istotę opcji rzeczywistych oraz ich podstawową klasyfikację. Sposób wykorzystania prostych opcji rzeczywistych zaprezentowano na przykładzie przedsiębiorstwa produkującego energię elektryczną i cieplną w kogeneracji. Możliwość wykorzystania opcji opóźnienia przedstawiono na przykładzie elektrowni atomowej. Został również zaprezentowany sposób wykorzystania złożonych opcji rzeczywistych na przykładzie zbywalnych jednostek do emisji gazów cieplarnianych przy finansowaniu restrukturyzacji przedsiębiorstwa.
\end{abstract}

\section{THE IMPACT OF THE GREENHOUSE GAS EMISSION ALLOWANCES TRADING SYSTEM ON THE ENTERPRISE VALUE}

Keywords: ETS, EU ETS, enterprise value, environmental protection, real options. JEL Classification: G23, Q51, Q52.

\begin{abstract}
The purpose of the paper is to present the possibilities to use environmental protection tools to manage and evaluate an enterprise. The paper presents the essence of real options and their basic classification. The way of using simple real options has been presented on the example of an enterprise which produces electricity and heating in co-generation. The potential to use the retard option has been presented on the
\end{abstract}

Data wpłynięcia: 25.03.2013; data zaakceptowania: 24.04.2013.

* Dane kontaktowe: paaweel@mat.umk.pl, Wydział Nauk Ekonomicznych i Zarządzania, Uniwersytet Mikołaja Kopernika, ul. Gagarina 13a, 87-100 Toruń, tel. 501559564. 
example of a nuclear energy plant. The manner to use complicated real options has been also shown on the example of transferable units for the greenhouse gas emission while financing an enterprise restructuring.

Translated by Paweł Jankowski

\section{WsTęP}

Prawidłowa wycena wartości przedsiębiorstwa jest jednym z podstawowych elementów podejmowania decyzji inwestycyjnych. Procesy globalizacyjne doprowadziły do szybkiego przepływu kapitału zarówno między poszczególnymi kontynentami, krajami, giełdami, jak i przedsiębiorstwami, w ten sposób przyczyniły się one do precyzyjniejszej wyceny wartości przedsiębiorstw. Jeden z elementów prawidłowej wyceny stanowi uwzględnienie zmieniających się przepisów prawnych, których wpływ na wartość przedsiębiorstwa jest trudny do określenia. Ochrona środowiska stała się realnym kosztem wraz z podpisaniem protokołu z Kioto. W niniejszym artykule, przy wykorzystaniu studiów literaturowych i własnej wiedzy zawodowej autora, podjęto próbę zbadania wpływu obowiązujących przepisów ochrony środowiska na wartość przedsiębiorstwa. Przedstawiono możliwości wykorzystania narzędzi ochrony środowiska do zarządzania i wyceny przedsiębiorstwa. Zagadnienie to zostało scharakteryzowane w oparciu o rachunek opcji realnych oraz na przykładzie kapitału ochrony środowiska w postaci bezpłatnie przyznawanych zbywalnych jednostek uprawnień do emisji gazów cieplarnianych. Zbywalne jednostki zostały wykorzystane w charakterze opcji rzeczywistych w przedsiębiorstwach obligatoryjnie uczestniczących w systemie handlu uprawnieniami do emisji gazów cieplarnianych.

\section{RYNKOWE MECHANIZMY W OCHRONIE ŚRODOWISKA}

Postępująca globalizacja doprowadziła do otwarcia poszczególnych gospodarek narodowych. Między krajami wytworzyły się nowe silniejsze powiązania systemów gospodarczych. W państwach, w których bezpośrednie koszty produkcji, takie jak energia elektryczna czy praca ludzka, są niższe i mocniej eksploatowane, zasoby naturalne zużywają się szybciej. W przypadku dóbr naturalnych nie istnieje prawo własności do fundamentalnych zasobów środowiska, takich jak powietrze czy woda. Brak prawa własności do określonych zasobów środowiska generuje problem podmiotu odpowiedzialnego za jego degradację. 
Koszty związane z użytkowaniem środowiska mają charakter odrębnych od przedsiębiorstwa, bardzo często publicznych, dlatego też większość dóbr i zasobów środowiska naturalnego należy traktować jako dobro publiczne (Żylicz 2004: 179-180). Na podstawie teorii ekonomicznych, m.in. teorii dóbr publicznych czy teorii efektów zewnętrznych, można stwierdzić, że istnieją wystarczające przesłanki do ingerencji państwa w ochronę środowiska. Taka ingerencja następuje przez zastosowanie odpowiedniej polityki prośrodowiskowej.

Wliteraturze są wyszczególniane narzędzia ochrony środowiska, które mają na celu wywarcie bezpośredniego lub pośredniego wpływu na zachowanie poszczególnych użytkowników środowiska. Ze względu na charakter instrumentów prośrodowiskowych można wyróżnić następujące trzy grupy: instrumenty zdecentralizowane, instrumenty bezpośredniego kierowania i kontroli oraz instrumenty ekonomiczne (Field 1994: 207-210; Verbruggen 1994: 55).

W ramach pierwszej grupy - instrumentów zdecentralizowanych, wyróżnia się ogólne przepisy prawa, takie jak np. odpowiedzialność cywilna, odpowiedzialność karna, prawo własności.

Do drugiej grupy - instrumentów bezpośredniego kierowania i kontroli, należą narzędzia o charakterze prawno-administracyjnym. Dzięki nim można bezpośrednio wpływać na zachowanie podmiotów gospodarczych. W tej grupie instrumentów są stosowane m.in. normy emisyjne, normy imisyjne, normy technologiczne, normy produktowe, normy postępowania (Śleszyński 2000: 190-191).

W ramach trzeciej grupy - instrumentów ekonomicznych, zgodnie z klasyfikacją przedstawioną przez OECD, wyróżnia się następujące narzędzia ekonomiczne: opłaty emisyjne, produktowe, użytkowników, administracyjne, systemy depozytowe, ubezpieczenia ekologiczne, subwencje i pozwolenia na korzystanie ze środowiska (Śleszyński 2000: 207). Ze względu na wywieranie pośredniego wpływu na podmioty gospodarcze narzędzia ekonomiczne są łagodniejszą formą oddziaływania niż regulacje prawno-administracyjne (Śleszyński 2000: 217-226). Do głównych zalet tej grupy instrumentów ekonomicznych można zaliczyć zarówno efektywność kosztową, jak i pobudzanie postępu technicznego oraz technologicznego. Podmioty gospodarcze w ekonomicznie optymalny sposób dostosowują swoją działalność do nowych norm (Managing the Environment. The Role of Economic Instruments 1994).

Jednym z rynkowych rozwiązań w ochronie środowiska są zbywalne pozwolenia na korzystanie ze środowiska. Jest to narzędzie polityki ochrony środowiska, którego podstawową koncepcję stanowi połączenie cech zarów- 
no regulacji bezpośredniej, jak i pośredniej. W tym przypadku regulacja bezpośrednia (administracyjna) wyprzedza regulację pośrednią (ekonomiczną). Wiąże się to z tym, że w pierwszej kolejności określany jest dopuszczalny zakres ingerencji w środowisko. Ten cel osiąga się przez wyznaczenie górnego pułapu dopuszczalnej wielkości emisji szkodliwych gazów cieplarnianych. W taki sposób jest również określana ilość zbywalnych uprawnień do emisji gazów cieplarnianych, która stanowi sumę wyznaczonego wcześniej pułapu. W efekcie dopuszczalna wielkość emisji została zestandaryzowana i podzielona na poszczególnych uczestników środowiska. W związku z tym dopuszczalna możliwa ingerencja w środowisko zaczęła być postrzegana jako przedmiot obrotu rynkowego w postaci zbywalnych uprawnień na okaziciela. Dzięki temu rozwiązaniu został osiągnięty zakładany poziom emisji gazów cieplarnianych przy zachowaniu trwałego i stabilnego rozwoju gospodarczego (Śleszyński 2000: 226-234).

Zastosowanie odpowiednich prośrodowiskowych instrumentów ochrony środowiska, które mają na celu przeciwdziałać negatywnym efektom zewnętrznym działalności produkcyjnej i konsumpcji, warunkuje możliwość oraz efektywne zarządzanie środowiskiem i jego naturalnymi zasobami. Dzięki temu możliwa jest skuteczna ochrona środowiska naturalnego w skali międzynarodowej. System zbywalnych pozwoleń na emisję gazów cieplarnianych pozwala na stworzenie wielu różnych giełdowych instrumentów finansowych opartych na cenie zbywalnych jednostek. W ten sposób zarządzający przedsiębiorstwami mają bezpośrednią możliwość zarządzania wartością firmy i jej wpływem na środowisko.

\section{CHARAKTERYSTYKA OPCJI RZECZYWISTYCH NA TLE OCHRONY ŚRODOWISKA}

Decyzje inwestycyjne bardzo często mają charakter nieodwracalny. W warunkach niepewności rezygnacja czy porzucenie projektu inwestycyjnego może wiązać się z wyższymi kosztami niż jego uruchomienie. Nowo napływające informacje podczas realizacji projektu mogą redukować to ryzyko. Tradycyjne techniki analityczne nie wyceniają jednak wartości elastyczności decyzyjnej. Opcje rzeczywiste są wynikiem kompleksowej analizy przedsiębiorstwa (Howell 2001). W takiej analizie uwzględnia się zarówno strukturę aktywów, jak i pasywów, ale także możliwość szybkiej zmiany decyzji ze względu na pojawiające się nowe informacje. Wartość elastyczności decyzyjnej może zostać wyceniona za pomocą analizy opcji realnych. 0 opcjach rzeczywistych 
mówi się wtedy, gdy decydent ma prawo podjąć decyzję w różnych momentach w przyszłości (Howell 2001).

Można hipotetycznie wyobrazić sobie projekt inwestycyjny składający się z dwóch etapów. Inwestor, podejmując decyzję o pierwszym etapie, może zrezygnować z drugiego lub odwlekać go w czasie. Możliwość porzucenia projektu przy drugim etapie jest swoistego rodzaju opcją. Opcje rzeczywiste są podobne do popularnych opcji finansowych. Nabycie opcji wiąże się z kosztem, który później może być zrewaluowany przez decydenta.

W sytuacji skrajnej niepewności możliwe jest budowanie racjonalnych strategii inwestycyjnych za pomocą narzędzia, jakie stanowi opcja realna. Opcja realna, zwana również opcją rzeczywistą, to pewna możliwość działania, którą może nabyć lub wytworzyć osoba fizyczna bądź firma (Houston, Brigham 2005: 117). Dzięki temu dysponent opcji realnej ma prawo do podjęcia określonej decyzji w zakresie zarządzania zasobami przedsiębiorstwa. Prawo to pozwala dostosować podjętą wcześniej decyzję do nowo pojawiających się informacji, które mogą istotnie wpłynąć na przepływy pieniężne inwestycji. Opcje rzeczywiste powinny być postrzegane jako inwestycje w aktywa trwałe - realne, które umożliwiają zarządzającemu przedsiębiorstwem elastyczne podejmowanie decyzji w zakresie ich wykorzystania (Mizerka 2005). W sytuacji, gdy rynkowe ceny surowców są nieprzewidywalne, każda podjęta przez zarządzającego przedsiębiorstwem decyzja jest obarczona ryzykiem. W celu wyeliminowania negatywnych skutków podejmowanych decyzji zarządzający powinni realizować projekty wieloetapowe. Każdy etap inwestycji powinien być traktowany jako odrębna opcja, np. kontynuacji inwestycji bądź jej zaniechania (Janney, Dess 2004: 60-75). Wczesne wyjście z projektu, jego zaniechanie prowadzi do minimalizacji strat związanych z błędnie podjętą decyzją inwestycyjną. Dobrym przykładem opcji rzeczywistej są przyznane nieodpłatnie uprawnienia do emisji gazów cieplarnianych. Uprawnienia te są codziennie wyceniane na giełdzie przez rynek. Odpowiednio wysoka cena uprawnień może doprowadzić do sytuacji, w której bardziej opłacalne będzie ich sprzedanie na giełdzie niż zużywanie przy produkcji. Posiadanie opcji realnej umożliwia zatem elastyczne zarządzanie wynikami ekonomicznymi przedsiębiorstwa w warunkach zwiększonej niepewności.

Opcje realne nie są przedmiotem obrotu giełdowego, dlatego nie można ich nabyć na giełdzie. Aby nabyć opcje realne, należy zakupić odpowiednie aktywa lub zespół aktywów. Ich właściwa analiza może zapewnić menadżerowi możliwość elastycznego zarządzania nimi. Opcje rzeczywiste są generowane przez 
wiedzę i umiejętności menadżerskie osób zarządzających danymi aktywami. Istnienie opcji realnych zależy również od uwarunkowań mikro- i makroekonomicznych. Nabycie opcji realnych wraz z zespołem aktywów może ulec zmianie ze względu na zmianę warunków prawnych, politycznych czy rynkowych. Tym samym oznacza to, że możliwość wykorzystania opcji realnych jest zmienna. Opcje realne związane $\mathrm{z}$ aktywami przedsiębiorstw zobligowanych do wypełniania obowiązków prośrodowiskowych mogą ulec zmianie, jeśli zmienią się restrykcje narzucane przez Unię Europejską w zakresie ochrony środowiska. W takim przypadku opcja realna wygaśnie.

Innym istotnym zagadnieniem jest wycena opcji realnych. Nabywca za opcje finansową płaci określoną przez uczestników obrotu giełdowego cenę. Opcja realna zależy od wiedzy zarządzających, toteż z jej uwzględnieniem dane przedsiębiorstwo zostanie wycenione. Decydent, który podejmie odpowiednią decyzję w warunkach niepewności przy niskiej wartości opcji realnej i podniesie jej wartość, pokazując innym inwestorom możliwość alternatywnego wykorzystania danego projektu, będzie mógł odsprzedać ten projekt z dużo wyższą wartością opcji realnej (Rogowski 2008).

Opcje realne w swojej istocie są bardzo podobne do opcji finansowych. Kontrakt opcyjny jest umową między nabywcą a sprzedawcą. Nabywca opcji ma prawo do kupna lub sprzedaży instrumentu bazowego (inaczej mówiąc - aktywa bazowego), na który opcja została wystawiona (Fabozzi 2000: 626). Wystawca natomiast ma obowiązek sprzedać lub kupić instrument bazowy, będący podstawą kontraktu. Opcje finansowe, które istnieją w obrocie giełdowym, są zestandaryzowane ze względu na podstawowe warunki kontraktu, takie jak cena, czas wykonania, cena wykonania. Główną zaletę kontraktu opcyjnego stanowi zatem niesymetryczny zakres praw i obowiązków wystawcy i nabywcy opcji (Gajdka, Walińska 2000: 355).

Podstawą kontraktu opcyjnego może być dowolny czynnik, który da się wyrazić liczbowo. Wycena giełdowych kontraktów opcyjnych może zależeć od cen towarów, np. pszenicy, cebulek tulipanów, ropy naftowej, srebra, złota, miedzi itp., jak i instrumentów finansowych, np. cen akcji, kursów walut, indeksów giełdowych, stóp procentowych. Cena opcji finansowych może być uzależniona od różnych wskaźników czy mierników, np. temperatury, wielkości produkcji, siły wiatru, wielkości opadów (Hull 1998: 199). Rozliczenie kontraktu opcyjnego może być również skonstruowane na bazie różnych kombinowanych wskaźników, takich jak np. wielkość zużycia paliwa w połączeniu z temperaturą czy wielkość produkcji w połączeniu z indeksem giełdowym. Ideę opcji 
rzeczywistej można zobrazować za pomocą przedsiębiorstwa produkującego ciepło i energię elektryczną. Ryzyka w takim przedsiębiorstwie mogą być analizowane ze względu na zależność między ceną energii elektrycznej i cieplnej, jak i ze względu na cenę surowców wykorzystywanych do jej produkcji. Ceny energii elektrycznej i cieplnej mogą być względem siebie niezależne. Przy założeniu, że rozwiązania techniczne w elektrociepłowni pozwalają na produkcję energii elektrycznej niezależnie od produkcji energii cieplnej, może okazać się, że produkcja energii elektrycznej przy jej niskich cenach będzie nieopłacalna. W przypadku braku zapotrzebowania na energię cieplną przychody ze sprzedaży energii elektrycznej przewyższą koszty jej produkcji. Paradoksalnie, korzystne regulacje prawne mogą przyczynić się do zwiększenia przychodów ze sprzedaży, np. ze względu na sposób, w jaki energia jest produkowana. Produkcja energii elektrycznej ze względu na korzyści płynące z kolorowych certyfikatów może okazać się mniej opłacalna niż produkcja w kogeneracji i braku przychodów z energii cieplnej. W tym przypadku na skutek elastyczności aktywów produkcyjnych przedsiębiorstwo produkujące energię jest posiadaczem opcji rzeczywistej.

W literaturze występuje wiele rodzajów klasyfikacji opcji realnych w zależności od możliwości, jakie one oferują. Opcje realne można podzielić na opcje proste i złożone, opcje wbudowane w projekty i opcje kreowane przez projekty, opcje wyłączne (propriety options) i opcje powszechne (shared options) (Jajuga, Jajuga 2008: 367). Do podstawowych opcji realnych, które mogą być wbudowane w projekty wymagające ponoszenia kosztów kapitałowych, można zaliczyć trzy opcje, takie jak: opcja porzucenia projektu, opcja opóźnienia projektu, opcja rozszerzenia projektu (Damodaran 2007: 599).

Opcja opóźnienia jest bardzo często stosowana przez spółki giełdowe. Daje ona możliwość czekania na odpowiednią koniunkturę giełdową i dopiero w takich warunkach pozwala przeprowadzić nową emisję akcji. Dobrym przykładem wykorzystania opcji opóźnienia projektu jest projekt budowy elektrowni atomowej w Polsce. Proces doboru jednej z pięciu lokalizacji odpowiedniej dla tej inwestycji będzie trwał tak długo, jak długo koszty związane z produkcją energii ze źródeł konwencjonalnych będą niższe niż koszty energii atomowej. Na te koszty maj wpływ nie tylko cena paliw typu węgiel, ale także instrumentów ochrony środowiska czy umów, do których Polska zobowiązuje się wobec innych krajów.

Opcja rozszerzenia projektu jest najczęściej stosowana przez przedsiębiorstwa, które chcą w przyszłości rozpocząć inne nowe projekty lub wejść 
na nowe rynki. Jest wykorzystywana w przypadku przedsiębiorstw realizujących np. duży projekt inwestycyjny, zakładający budowę zespołu budynków mieszkalno-usługowych, składający się z kilku etapów - wielu budynków wielorodzinnych. Przedsiębiorstwa mogą uzależnić realizację poszczególnych etapów projektu, jak i budowy poszczególnych budynków od różnych czynników, np. od popytu na nieruchomości.

Opcje realne są klasyfikowane w zależności od możliwości, jakie oferują. Najbardziej typowym podziałem opcji realnych, choć niewyczerpującym wszystkich możliwości, jest podział zaproponowany przez Copelanda i Keenana. Został on zobrazowany na schemacie 1.

Schemat 1. Podział opcji realnych

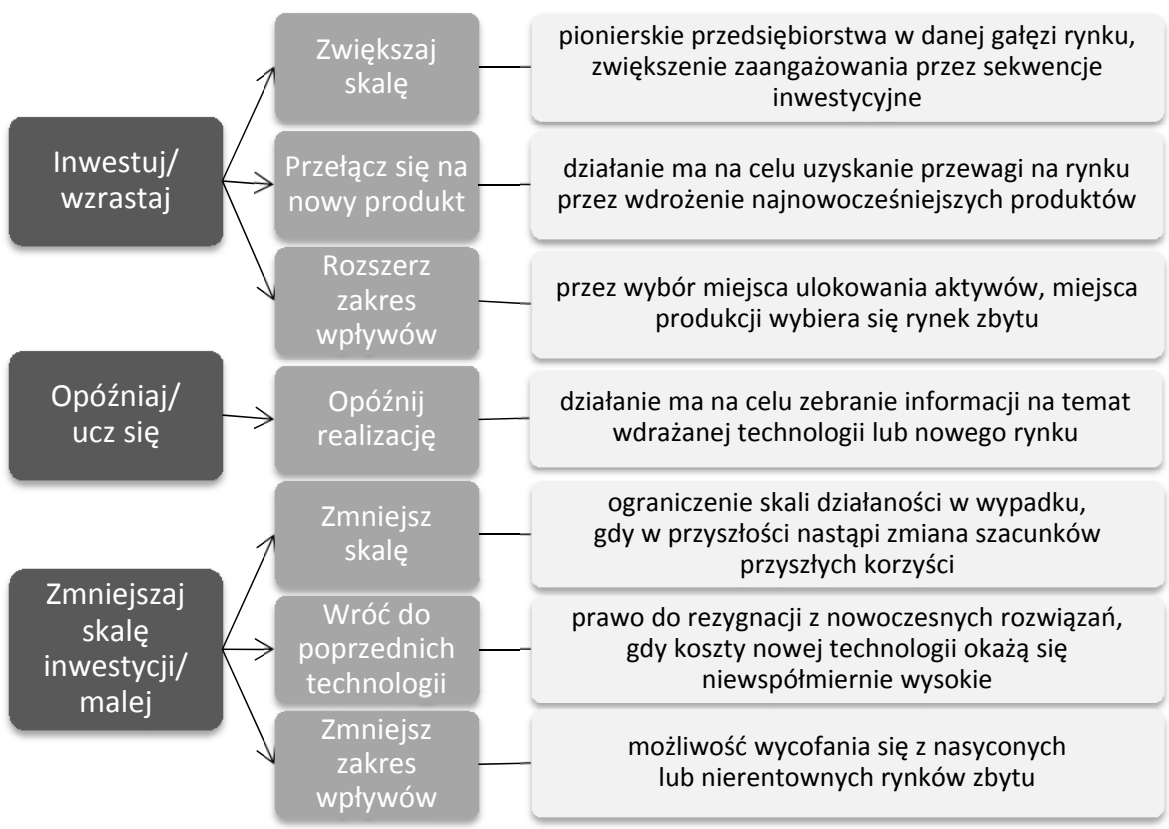

Źr ó d ł o : Copeland, Keenan 1998: 48.

Podstawowym podziałem opcji realnych zaproponowanym przez Copelanda i Keenana jest wyodrębnienie opcji inwestowania, opcji opóźnienia oraz opcji zmniejszających skalę. Opcje inwestowania dzieli się na opcje zwiększające skalę, opcje przełączające na nowe produkty i opcje rozszerzające zakres wpływów. Opcje zmniejszające skalę inwestycji dzieli się na opcje zmniejsza- 
jące skalę działalności, opcje powrotu do poprzednich technologii oraz opcje zmniejszające zakres wpływów.

W ramach zarządzania opcjami wyróżnia się dwa podejścia: bierne i aktywne. Inwestor, planując inwestycję, może podjąć decyzję o rozpoczęciu inwestycji lub wstrzymać się od jej podjęcia, tym samym wykorzystując opcję opóźnienia (Szablewski, Tuzimek 2004: 233-234). Opcje opóźnienia są wykorzystywane przy projektach o wyższym ryzyku i relatywnie niskiej stopie zwrotu. Odsunięcie decyzji inwestycyjnej w czasie, do momentu uchwalenia nowych ustaw czy porozumień międzynarodowych, jest stosowane w przypadku projektów bardziej ryzykownych.

\section{WYKORZYSTANIE OPCJI RZECZYWISTYCH W PRZEDSIĘBIORSTWIE - PRZYKEAD CIEPEOWNI}

Przedsiębiorstwa z sektora energetycznego, chemicznego czy cementowego, które posiadają bezpłatnie przyznane jednostki uprawniające do emisji gazów cieplarnianych, mogą skorzystać z opcji przełączenia lub zmniejszenia skali produkcji. Limity uprawnień do emisji zostały przyznane na podstawie wyliczeń i kalkulacji historycznych, dlatego szczególnie dużo zyskały przedsiębiorstwa, które odnotowały spadek popytu na swoje produkty. Dzięki przyznanym limitom uprawnień i możliwości ich sprzedania na rynku giełdowym przedsiębiorstwa te mogły zaprzestać produkcji. Przychody były osiągane ze sprzedanych praw do emisji. Przychody z niewykorzystanych praw do emisji mogły zostać wykorzystane do przystosowania przedsiębiorstwa do zmieniających się warunków rynkowych. Taka restrukturyzacja to zastosowanie dwóch opcji rzeczywistych. W pierwszej fazie - opcja zastąpienia przychodów operacyjnych z produktu podstawowego przychodem ze zbywalnych jednostek. W następnej fazie - opcja zmiany produktu, wykorzystywanego paliwa lub działalności na taką, która lepiej spełniała wymogi klientów. W powyższym przykładzie została zaprezentowana idea wykorzystania opcji złożonych (ang. compound options). Należy pamiętać, że typowe projekty to zbiór wielu opcji, bardzo często wzajemnie od siebie zależnych.

\section{ZAKOŃCZENIE}

Narzędzia ochrony środowiska odgrywają coraz większą rolę w zarządzaniu przedsiębiorstwem. W 2005 roku zbywalne jednostki zostały zestandaryzo- 
wane i wprowadzone do obiegu giełdowego oraz stały się znaczącym elementem zarówno kosztowym, jak i przychodowym w finansach przedsiębiorstw. Niezbędne jest zatem uwzględnienie czynników ochrony środowiska w zarządzaniu przedsiębiorstwem. Kluczem może być wykorzystanie opcji rzeczywistych do wyceny czy planowania projektów inwestycyjnych w celu zdobycia trwałej przewagi konkurencyjnej na arenie międzynarodowej. Wartość opcji rzeczywistej jest rezultatem możliwości kreowania dodatkowych zysków ekonomicznych w sytuacji, gdy przedsiębiorstwo musi efektywnie dostosowywać się do nieoczekiwanych zmian w swoim otoczeniu. W związku z tym ma ono możliwość zwiększania wartości dodanej w wyniku zarówno identyfikacji, zarządzania, jak i wykonywania opcji rzeczywistej związanej z jego działaniem. Pozwala to na odpowiednie podejmowanie decyzji i wykorzystywanie pojawiających się szans, aby ograniczać wpływ ryzyka finansowego na wyniki ekonomiczne przedsiębiorstwa.

W artykule zostały przedstawione możliwe zastosowania opcji rzeczywistych w przedsiębiorstwach szczególnie intensywnie wykorzystujących środowisko naturalne. Instrumenty ochrony środowiska stają się istotnym elementem rozwoju rynków finansowych. Należy zaznaczyć, że niniejszy artykuł ma charakter wprowadzający do szerokiej dyskusji na temat wpływu przepisów ochrony środowiska oraz urynkowienia regulacji prośrodowiskowych na wartość przedsiębiorstwa.

\section{LITERATURA}

Copeland T. E., Keenan P. T. (1998), How much is exibility worth?, McKinsey Quartely, no. 2. Damodaran A. (2007), Finanse korporacyjne. Teoria i praktyka, Wydawnictwo Helion, Gliwice.

Fabozzi F. J. (2000), Rynki obligacji. Analiza i strategie, WIG-Press, Warszawa.

Field B. (1994), Environmental Economics. An Introduction, McGraw-Hill, New York.

Gajdka J., Walińska E. (2000), Zarzq̨dzanie finansami. Teoria i praktyka, t. 2, Fundacja Rozwoju Rachunkowości w Polsce, Warszawa.

Houston J. F., Brigham E. F. (2005), Podstawy zarzqdzania finansami, wyd. 2, PWE, Warszawa.

Howell S. (2001), Real Options. Evaluating Corporate Investment Opportunities in a Dynamic World, Pearson Education Limited.

Hull J. (1998), Kontrakty terminowe i opcje, Wydawnictwo Finansowe WIG-Press, Warszawa.

Jajuga K., Jajuga T. (2008), Inwestycje: instrumenty finansowe, aktywa niefinansowe, ryzyko finansowe, inżynieria finansowa, PWN, Warszawa. 
Janney J., Dess G. (2004), Can Real-Options Analysis Improve Decision-Making? Promises and Pitfalls, The Academy of Management Executive, vol. 18, no. 4, 60-75, doi: http:// dx.doi.org/10.5465/AME.2004.15268687.

Managing the Environment. The Role of Economic Instruments, OECD, Paris 1994.

Mizerka J. (2005), Opcje rzeczywiste w finansowej ocenie efektywności inwestycji, Prace habilitacyjne 20, Wydawnictwo Akademii Ekonomicznej w Poznaniu, Poznań.

Rogowski W. (2008), Opcje realne w ocenie przedsięwzięć inwestycyjnych, [w:] Opcje realne $w$ przedsięwzięciach inwestycyjnych, red. W. Rogowski, Oficyna Wydawnicza SGH, Warszawa.

Szablewski A., Tuzimek R. (2004), Wycena i zarzq̨dzanie wartościa firmy, Wydawnictwo POLTEXT, Warszawa.

Śleszyński J. (2000), Ekonomiczne problemy ochrony środowiska, ARIES, Warszawa.

Teach E. (2003), Will real options take root?, CFO, July.

Verbruggen H. (1994), The Trade Effects of Economic Instruments, Environmental Policies and Industrial Competitiveness, OECD, Paris.

Żylicz T. (2004), Ekonomia środowiska i zasobów naturalnych, PWE, Warszawa. 
